\title{
METHODS FOR THE ASSESSMENT OF TOURIST DESTINATIONS COMPETITIVENESS
}

\section{PIOTR GRYSZEL}

\begin{tabular}{|c|c|}
\hline & $\begin{array}{l}\text { Wrocław University of Economics } \\
\text { e-mail: piotr.gryszel@ue.wroc.pl }\end{array}$ \\
\hline $\begin{array}{l}\text { RECEIVED } \\
\text { ACCEPTED }\end{array}$ & $\begin{array}{l}20 \text { March } 2015 \\
1 \text { June } 2015\end{array}$ \\
\hline $\begin{array}{l}\text { JEL } \\
\text { CLASSIFICATION }\end{array}$ & C38, L83, R12 \\
\hline KEYWORDS & competitiveness of tourist destinations, synthetic measures, competitiveness indicators \\
\hline ABSTRACT & $\begin{array}{l}\text { The establishment of regional competitiveness represents one of the methods applied for the purposes of effec- } \\
\text { tive competition between tourist destinations at the broadly understood tourist market. Competitiveness itself } \\
\text { represents a complex phenomenon which can be understood in different ways. It can also be analysed in many } \\
\text { perspectives. Owing to its complexity the assessment of competitiveness is not an easy task. Diverse competi- } \\
\text { tion indicators are used in practice, however, they do not present the full complexity of the entire phenomenon. } \\
\text { Synthetic measures seem to be one of the best methods to assess the competitiveness of tourist destinations. } \\
\text { Their specification allows for the evaluation of phenomena influenced by numerous variables. The purpose of } \\
\text { the article is to review methods and measures used for the assessment of tourist destinations competitiveness } \\
\text { as well as their practical application. }\end{array}$ \\
\hline
\end{tabular}

\section{Introduction}

Such phenomena as competition, competitive advantage and competitiveness in relation to market economy are broadly discussed and analysed by economists. For a long time they have been studied mainly with reference to enterprises, whereas the new European Union regional policy, with its crucial priority of increasing regional competitiveness as the significant driving force underlying regional development, resulted in regional competitiveness 
becoming the core interest of regional studies. It is assumed that regional competitiveness represents the means (tool) to achieve the general objective of social development, i.e. the growth of regional revenues and wealth.

One of the first definitions of competitiveness is the definition by the British Finance Minister (1983) referring to competitiveness in an international perspective: International competitiveness means the ability of a country's producers to compete successfully in world markets and with imports in its own domestic market. Competitiveness is generally measured by the shares which a country attains in its markets, due allowance being made for its size and stage of development. Hong (2005: 35 ) says that competitiveness in this very general sense comes to being synonymous with overall economic performance.

The concept of regional competitiveness, including tourism oriented regions, is a complex concept. Many various factors of both, objective and subjective nature exert impact on the competitiveness of tourist destinations. Instead of presenting the substantive definition of tourist destinations competitiveness, it is most frequently referred to in the form of diverse models. The most popular and most often quoted models have been suggested by J.R.B. Ritchie and G.I. Crouch (Crouch, Ritchie, 1999), as well as L. Dwyer and C. Kim (Dwyer, Kim, 2001; 2003). The first model presents 34 factors divided into 5 groups, which is illustrated on Figure 1.

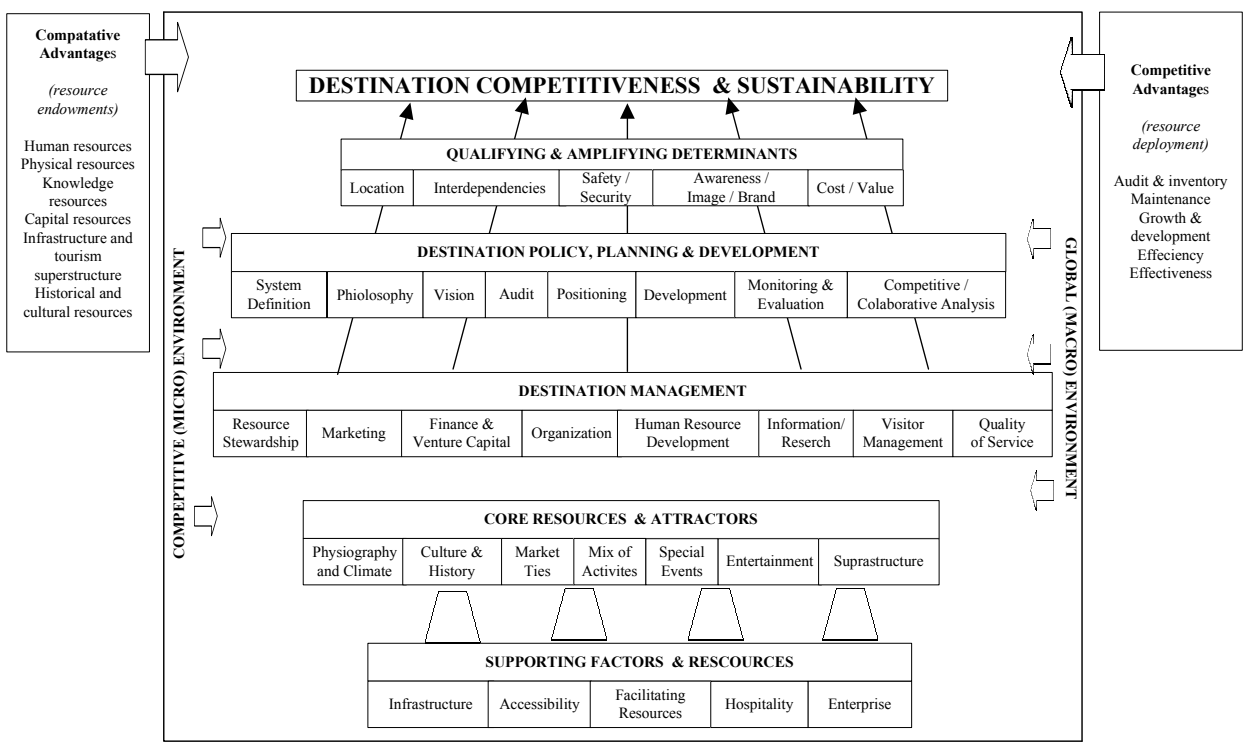

Figun 1. The model of tourist destinations competitiveness according to J.R.B. Ritchie and G.I. Crouch Source: Ritchie, Crouch (2005): 63.

The latter model, on the other hand, is based on 9 groups of factors presented on Figure 2.

It can be assumed that a competitive tourist destination is the one which is capable of presenting a tourist offer at both, domestic and international tourism market, so that it results in economic and non-economic effects for its residents and the other interested entities. It is a region capable of winning the competition against the other regions, which results in higher life quality experienced by its residents. 


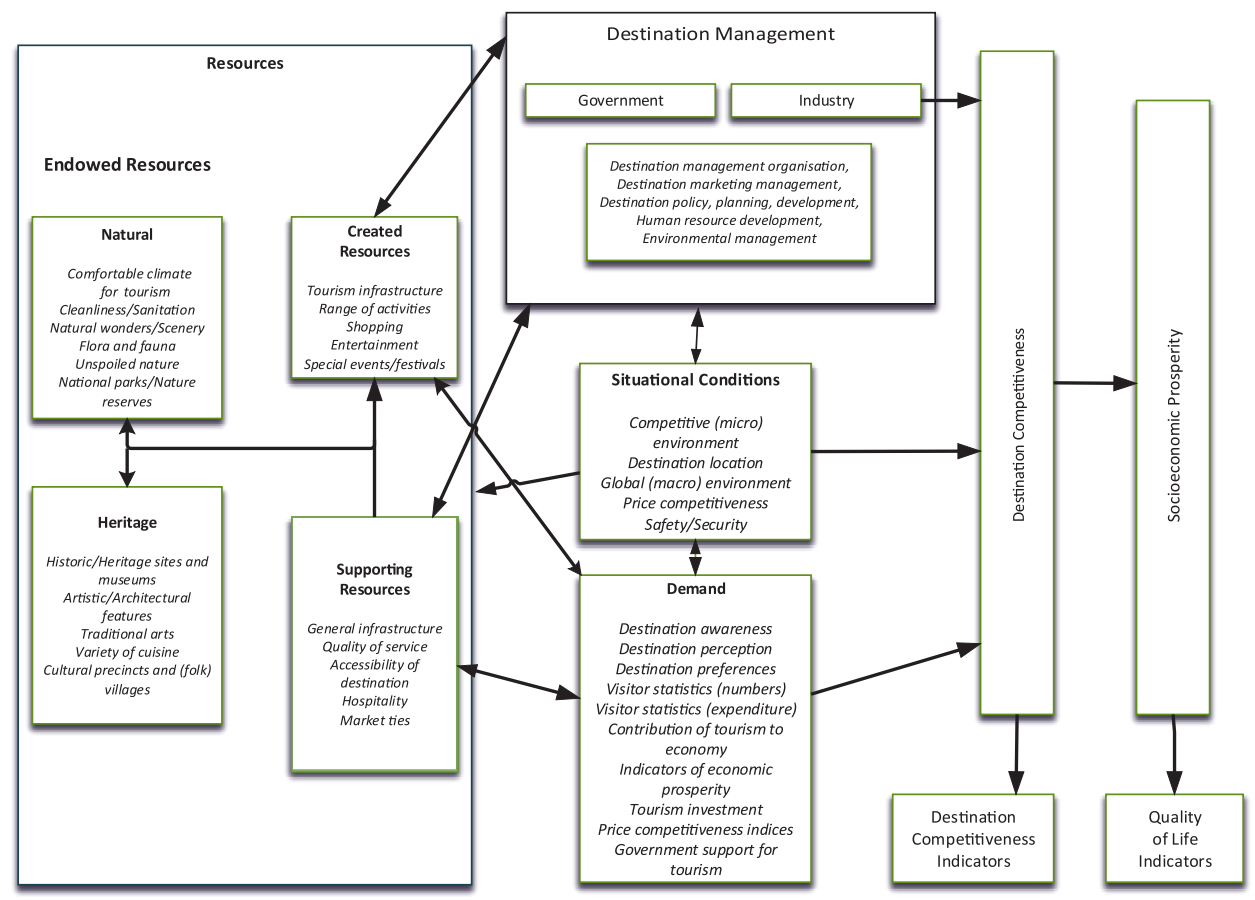

Figulp 2. The main elements of destination competitiveness

Source: Dwyer, Kim (2003): 378.

\section{The selected measures of tourist destinations competitiveness}

One of the most frequently applied measures of regional competitiveness is the gross domestic product per one inhabitant. It is, however, a very general measure not offering much information about the reasons or components of general value. The decomposition of GDP from the general value allows for considering the wide spectrum of social and economic processes. The main goal of such decomposition is to identify factors which determine the diversification of GDP per capita for particular regions against the average level of the entire economy. This value can present a statistical or dynamic nature by means of comparing differences in particular periods. GDP per capita (as logarithm) in $i$ region can be presented as:

where:

$$
\log \frac{\mathrm{PKB}_{i}}{\mathrm{P}_{\mathrm{i}}}=\log \frac{\mathrm{PKB}_{\mathrm{i}}}{E W_{i}}+\log \frac{E W_{i}}{\mathrm{LFW}_{i}}+\log \frac{\mathrm{LFW}_{\mathrm{i}}}{\mathrm{LFR}_{\mathrm{i}}}+\log \frac{\mathrm{LFR}_{\mathrm{i}}}{\mathrm{P}_{\mathrm{i}}}
$$

P - total population,

EW - employment at workplace,

LFW - labour force at workplace,

LFR - resident labour force. 


$$
\mathrm{LFW}_{\mathrm{i}}=\mathrm{LFR}_{\mathrm{i}}+\mathrm{NC}_{\mathrm{i}}
$$

where $\mathrm{NC}_{\mathrm{i}}-$ number of commuters.

This indicator can be applied in the assessment of international competitiveness referring to particular countries. In terms of regions, however, one comes across problems of some statistical data availability. Firstly, data are most often collected for NUTS 1 and NUTS 2 levels. Smaller regions cannot be assessed in this way. Secondly, the borders of tourist regions are very rarely the same as the borders of administrative units, which makes the collection of reliable statistical data even more difficult. Moreover, it remains a very difficult task to assess the regional GDP per capita indicator which has been worked out specifically in tourism economy. It is related to the fact that the concept of tourism economy itself is perceived differently in various countries. Additionally, this factor does not cover certain crucial qualities characteristic for regional competitiveness, such as e.g.: knowledge resources, infrastructure, innovation or location - the component very important in tourism.

While discussing tourism economy one refers to a particular sector of economy. In this case the so-called sector oriented concentration is of great importance, since it reflects the level of economic variables concentration along the regional sectors. In this case RCA ratio (Revealed Comparative Advantage) can be applied. Its author is Bala Balassa and the indicator itself is also referred to as the concentration ratio used to analyse the level of regional sector concentration. Tourism economy can also represent such a concentrated sector. $R C A$ ratio can be calculated according to the following formula:

where:

$$
\operatorname{RCA}_{i j}=\frac{E_{i j} E}{E_{i} E_{j}}
$$

$\mathrm{E}_{\mathrm{ij}}$ - the analysed variable in $i$ sector (branch of industry) in $j$ region, where $i=1,2, \ldots, I$ and $j=1,2, \ldots, R$,

$E_{j}$ - the analysed variable in $j$ region,

$\mathrm{E}$ - the analysed variable in the entire area and in all sectors.

This indicator reflects the sector's share in regional economy adequately to this sector's share in the entire national economy. $R C A$ value higher than 1 means that the region presents the revealed comparative advantage of this particular economy branch, i.e. specializes in this branch. If, on the other hand, $R C A$ is lower than 1 then the region does not present such advantage and is relatively unspecialised in this branch of economy. In case of tourist destinations the analysed economy branch (sector) can be regarded as tourism economy (Łaźniewska and Gorynia, 2012: 80-89).

Similarly to the GDP per capita indicator, while estimating RCA indicator one can come across the barrier of reliable statistical data availability for the level lower than NUTS 2. Moreover, specifying the scope of tourism economy also constitutes a problem. It can be done by means of tourism satellite account, however, its calculation methodology still remains at the consultation stage and thus tourism satellite account is regarded as insufficiently precise in terms of methodology.

Travel \& Tourism Competitiveness Index (TTCI), suggested by the World Economic Forum, can be applied as the measure taking into account the specific nature of tourism economy and allowing for the assessment of tourist destinations competitiveness. It is probably the most popular and empirically implemented index used by 
WEF to assess the tourism competitiveness of countries. It can also be applied in the assessment of regional competitiveness. $\mathrm{TTCl}$ is composed of partial indices covering the problems of tourism legal environment, tourism business environment and infrastructure, human, cultural and natural tourism resources (Table 1). Each partial index is composed of the so-called sub-indices referring to the particular topics and grouping problems considered as adequate for a given sub-index. E.g. A sub-index called "safety and control" covers, among others, the costs of terrorism for business, the reliability of police services, the costs of riots and criminal offences for business, road accidents. The indicators used to calculate particular sub-indices cover both, the assessment of resources which can be presented in the form of numerical data (e.g. the number of beds in accommodation facilities, government expenditure on tourism), economic data (taxes, price competitiveness, airport charges), as well as the subjective feelings (e.g. the above-mentioned reliability of police services). Therefore, in the course of preparing sub-indices both, the statistical data and the opinions of experts representing international corporations are taken into account, which results in controversies regarding the objectivism of the achieved results.

Table 1. Travel \& Tourism Competitiveness Index (TTCI)

\begin{tabular}{|c|c|c|c|}
\hline \multicolumn{4}{|c|}{ Travel \& Tourism Competitiveness Index } \\
\hline subindeks $A$ & subindeks B & subindeks $\mathrm{C}$ & subineks $\mathrm{D}$ \\
\hline Enabling Environment & T \& T Policy and Enabling Conditions & Infrastructure & Natural and Cultural Resources \\
\hline $\begin{array}{l}\text { Business Environment } \\
\text { (12 indicators) }\end{array}$ & $\begin{array}{c}\text { Prioritization of Travel \& Tourism } \\
\text { (6 indicators) }\end{array}$ & $\begin{array}{c}\text { Air Transport Infrastructure } \\
\text { (6 indicators) }\end{array}$ & $\begin{array}{l}\text { Natural Resources } \\
\text { (5 indicators) }\end{array}$ \\
\hline $\begin{array}{l}\text { Safety and Security } \\
\text { (5 indicators) }\end{array}$ & $\begin{array}{l}\text { International Openness } \\
\quad \text { (3 indicators) }\end{array}$ & $\begin{array}{l}\text { Ground and Port Infrastructure } \\
\text { (7 indicators) }\end{array}$ & $\begin{array}{l}\text { Cultural Resources } \\
\text { and Business Travel } \\
\text { (5 indicators) }\end{array}$ \\
\hline $\begin{array}{l}\text { Health and Hygiene } \\
\text { ( } 6 \text { indicators) }\end{array}$ & $\begin{array}{l}\text { Price Competitiveness } \\
\text { (4 indicators) }\end{array}$ & $\begin{array}{l}\text { Tourist Service Infrastructure } \\
\text { ( } 4 \text { indicators) }\end{array}$ & \\
\hline $\begin{array}{c}\text { Human Resources and Labour } \\
\text { Market } \\
\text { (9 indicators) }\end{array}$ & $\begin{array}{l}\text { Environmental Sustainability } \\
\text { (10 indicators) }\end{array}$ & & \\
\hline $\begin{array}{l}\text { ICT Readiness } \\
\text { (8 indicators) }\end{array}$ & & & \\
\hline
\end{tabular}

Source: World Economic Forum (2015): 4.

This index allows for preparing rankings of tourist destinations competitiveness and its variable values are in the range from 1 up to 7 . All the variables which do not originate from interviews are standardized according to the below formula:

where:

$$
6 \times\left(\frac{\mathrm{CS}-\mathrm{Smin}}{\mathrm{Smax}-\mathrm{Smin}}\right)+1
$$

$$
\begin{aligned}
& \text { CS - country score, } \\
& \text { Smin - sample minimum, } \\
& \text { Smax - sample maximum. }
\end{aligned}
$$


The empirical application of $T T C l$ is, however, quite time consuming and requires extensive surveys and interviews. Such procedure significantly raises the costs of this index application. Definitely, even tourism oriented regions earning large revenues generated by tourism economy would have doubts about covering such extensive costs to estimate $T T C l$. It probably represents one of the major reasons underlying the absence of this index application with reference to particular tourist destinations.

The comparison of multivariate objects is of particular significance in the assessment of tourist destinations competitiveness. Taxonomy plays the crucial role in solving problems of assigning multivariate objects space. Currently taxonomic methods and synthetic measures of development are used mostly by researchers. The empirical application of one of the synthetic measures is presented in another article by the author (Gryszel, 2014).

At this point, however, it is worth indicating the possibility of using the synthetic measure of development for the assessment of tourist destinations competitiveness, in case of which the distances between particular objects (regions) from the model object are determined by means of the generalised distance measure (GDM) (Walesiak, 2011: 76-78):

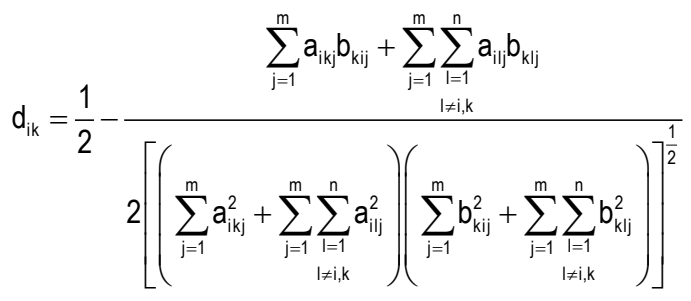

where:

$\mathrm{d}_{\mathrm{iw}}-$ GDM distance measure of $i$-th object from $w$ model-object,

$p=w, l ; r=i, l ; i, I=1, \ldots, n$ - object's number,

w - model-object number,

$\mathrm{j}=1, \ldots, \mathrm{m}-$ variable number,

$\mathrm{w}_{\mathrm{j}}-j$-th variable weight.

If substitution (6) is applied in formula (5) GDM1 distance is obtained for metrical data (quotient or interval):

$$
\begin{array}{lll}
a_{i p j}=z_{i j}-z_{p j} & \text { dla } & p=w, l \\
b_{w r j}=z_{w j}-z_{r j} & \text { dla } & r=i, l
\end{array}
$$

where: $z_{i j}\left(z_{\mathrm{lj}}\right)-i$-th $(I-$ ta) normalized observation on $j$-th variable.

On the other hand, using substitution (7) in formula (5) allows for obtaining GDM2 distance for ordinal data:

$$
a_{i p j}\left(b_{k r j}\right)=\left\{\begin{aligned}
1, & \text { jeżeli } x_{i j}>x_{p j}\left(x_{k j}>x_{r j}\right) \\
0, & \text { jeżeli } x_{i j}=x_{p j}\left(x_{k j}=x_{r j}\right) \\
-1, & \text { jeżeli } x_{i j}<x_{p j}\left(x_{k j}<x_{r j}\right),
\end{aligned}\right.
$$


The properties of GDM measure in linear ordering are as follows (vide Walesiak, 2011: 44-46):

- it takes values in $[0 ; 1]$ range. 0 value means that for the compared $i, k$ objects only equality relationships are present between the respective variable observations. If (7) is substituted the value of 1 means that for the compared $i, k$ objects only the majority (minority) or majority (minority) and equality relationships occur between the respective observations on ordinal variables, if these relationships are maintained with respect to the remaining objects (thus the objects having numbers $I=1, \ldots, n$; where $I \neq i, k$ ),

- it meets the conditions of non-negativity $d_{i w} \geq 0$, reflexivity $d_{i i}=0$, symmetry $d_{i w}=d_{w i}$,

- at least one pair of objects is present in $A$ set of analysed objects for which the observations on variables are not identical (to avoid zero in $d_{i w}$ denominator),

- if there are only two $d_{i w}=1$ objects in the set of objects,

- the value is not changed as a result of variable values transformations by means of the permitted, in a given scale, mathematical transformation (in ordinal scale: any strictly monotonic function; in interval scale: linear function; in quotient scale: homogenous linear function).

The empirical application of one of the GDM measures is presented in another article by the author (Gryszel, Walesiak, 2014)

\section{Final conclusions}

The conducted analyses allow concluding that measuring the level of tourist destinations competitiveness is not an easy task since the definition of regional competitiveness itself constitutes the basic problem, as well as determining the scope of tourism economy concept, i.e. which economic activity performed in a region is related to tourism and which is not. Collecting reliable statistical data, covering small tourist destinations, is also highly problematic. It is much easier to obtain statistical data referring to particular countries or regions (NUTS 1 and NUTS 2) than those covering lower level units. Moreover, in case of constructing indices doubts are raised in terms of information collected in the course of survey studies or expert interviews, and in case of synthetic measures the set of selected explanatory variables is most often a disputable one. It has to be emphasized, however, that synthetic measures based on statistical data offer the least controversial results carrying the lowest error burden resulting from the discretion and non-measurability of explanatory data.

\section{References}

Hong, W. (2008). Competitiveness in the Tourism Sector. A Comprehensive Approach from Economic and Management Points. Heidelberg: Physica-Verlag.

Crouch, G. \& Ritchie, J. (1999). Tourism, competitiveness, and societal prosperity. Journal of Business Research, 44: 137-152.

Dwyer, L. \& Kim, C. (2003). Destination competitiveness: Determinants and indicators. Current Issues in Tourism, 6 (5).

Dwyer, L., Kim, Ch., Choi, K., Faulkner, B, Mellor, R. \& Livaic, Z. (2001). Destination Competitiveness: Development of a Model with Application to Australia and Republic of Korea. Korea Tourism Research Institute, Ministry of Culture and Tourism, AustraliaKorea Foundation.

Gryszel, P. (2014). The assessment of tourist destinations competitiveness using a synthetic measure. In: Management 2014. Business, management and social sciences research. Eds. R. Štefko, M. Frankovský, J. Vravec. Prešov: Prešovska univerzita v Prešove (pp. 277-283).

Gryszel, P. \& Walesiak, M. (2014). Zastosowanie uogólnionej miary odległości GDM w ocenie atrakcyjności turystycznej powiatów Dolnego Śląsk. Folia Turistica, 31. Kraków: Akademia Wychowania Fizycznego w Krakowie (pp. 127-148). 
Łaźniewska, E., Gorynia, M. (eds.) (2012). Konkurencyjność regionalna. Koncepcje - strategie - przykłady. Warszawa: Wydawnictwo Naukowe PWN.

Ritchie, J.R.B. \& Crouch, G.I. (2005). The Competitive Destination: A Sustainable Tourism Perspective. London: CABI.

World Economic Forum (2015). The Travel \& Tourism Competitiveness Report 2015. Geneva: World Economic Forum.

Walesiak, M. (2011). Uogólniona miara odległości GDM w statystycznej analizie wielowymiarowej z wykorzystaniem programu R. Wrocław: Wydawnictwo Uniwersytetu Ekonomicznego we Wrocławiu.

Cite this article aS: Gryszel, P. (2015). Methods for the assessment of tourist destinations competitiveness. Szczecin University Scientific Journal, No. 872. Service Management, 15 (1): 41-48. 